Viso - Cadernos de estética aplicada Revista eletrônica de estética

ISSN 1981-4062

No 18, jan-jun/2016

http://www.revistaviso.com.br/

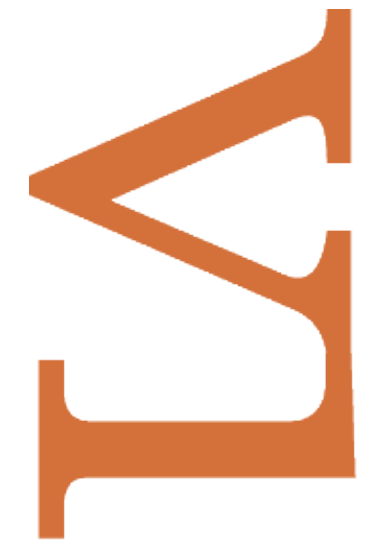

\title{
Mito e modernidade: Diálogos com Leucó e tragédia contemporânea Daniel Alves Gilly
}




\section{RESUMO}

\section{Mito e modernidade: Diálogos com Leucó e tragédia contemporânea}

O presente trabalho parte de uma análise da reinvenção dos mitos gregos antigos realizada na obra "Diálogos com Leucó", de Cesare Pavese, buscando entender até que ponto o modo como o autor reescreve subversivamente essa tradição consegue fazer com que ela alcance novos significados e nova relevância para a sociedade contemporânea. Entendendo que os mitos gregos transmitem um contínuo e inevitável conflito do humano contra a natureza e os deuses, Pavese contrapõe a esse mundo primordial a sociedade industrial do pós-guerra eurpoeu, na qual se reatualizariam os conflitos contra as potências míticas que governam o mundo. Os mitos se tornam assim transmissão da condição universal e inescapável que é dada pelo destino humano, pois é criação constantemente renovada pela fala dos deuses superiores. E a poesia, enquanto linguagem pela qual o mortal se comunica com a fala divina, é a eterna tentativa humana de criar um destino diverso, uma outra fala para uma outra relação com os deuses.

Palavras-chave: mito - modernidade - Pavese - tragédia

\section{ABSTRACT}

\section{Myth and Modernity: Dialogues with Leuco and Contemporary Tragedy}

The present work takes off with an analysis of the reivention of ancient greek myths fulfilled in the work "Dialogues with Leuco", by Cesare Pavese, seeking to undertand to what extent the way the author subversively rewrites this tradition succeed to make it achieve new meanings and new relevance to contemporary society. Understanding that greek myths transmit a continuous and inevitable conflict of human against the nature and the gods, Pavese opposes this primordial world to industrial society of the european post-war, where would be re-enacted the conflicts against the mythical powers that govern the world. The myths would then become transmission of the universal and inescapable condition given by the human destiny, because it is constantly renewed criation by the speech of the superior gods. And poetry, while language by whuch the mortal comunicates with divine speech, is the eternal human attempt of criating a different desntiny, another speech for another relationship with the gods.

Keywords: myth - modernity - Pavese - tragedy 


\section{GILLY, D. "Mito e modernidade: Diálogos com Leucó e tragédia contemporânea". In: Viso: Cadernos de estética aplicada, v. X, n. 18 (jan-jun/2016), pp. 95-110.}

DOI: 10.22409/1981-4062/v18i/220

Aprovado: 05.01.2016. Publicado: 03.07.2016.

(C) 2016 Daniel Gilly. Esse documento é distribuído nos termos da licença Creative Commons Atribuição-NãoComercial 4.0 Internacional (CC-BY-NC), que permite, exceto para fins comerciais, copiar e redistribuir o material em qualquer formato ou meio, bem como remixá-lo, transformá-lo ou criar a partir dele, desde que seja dado o devido crédito e indicada a licença sob a qual ele foi originalmente publicado.

Licença: http://creativecommons.org/licenses/by-nc/4.0/deed.pt_BR

Accepted: 05.01.2016. Published: 03.07.2016.

(C) 2016 Daniel Gilly. This document is distributed under the terms of a Creative Commons Attribution-NonCommercial 4.0 International license (CC-BY-NC) which allows, except for commercial purposes, to copy and redistribute the material in any medium or format and to remix, transform, and build upon the material, provided the original work is properly cited and states its license.

License: http://creativecommons.org/licenses/by-nc/4.0/ 
Com delirante boca, sem risos, sem pinturas e sem bálsamos,

emite a Sibila através do deus a voz que ultrapassa mil anos

Heráclito

Diálogos com Leucó, de Cesare Pavese, é uma indagação sobre a amplitude do lugar ocupado pelo homem no mundo, e mais ainda, sobre as suas possibilidades de atuação neste mundo, condicionadas pela sua capacidade ou incapacidade de ver e se posicionar nele. A crítica que se pegou desarmada no momento de seu lançamento pensou ter se deparado com um retrocesso na visão de seu autor sobre as possibilidades do fazer artístico como uma construção política, já que as reflexões sobre a divindade, a morte e o destino tomavam na obra o lugar dos temas mais discutidos na época, particularmente pelo neorrealismo.

Esta mudança se refere àquilo que o autor chamou de desconfiança de que o passado mítico da humanidade, o destino do homem como foi refletido pelos mitos gregos, estava realmente morto. De acordo com as próprias palavras de Pavese:

Deixou por um momento de acreditar que o seu totem e tabu, os seus selvagens, os espíritos da vegetação, o assassinato ritual, a esfera mítica e o culto dos mortos foram esquisitices inúteis e quis procurar neles o segredo de algo que todos recordam, todos admiram meio a contragosto e de que sorriem bocejando. ${ }^{1}$

A pretensão de tomar como objeto a realidade contemporânea, para a partir de sua descrição orientar a ação política, foi deixada de lado para que se buscasse colocar de maneira fundamental a questão mesma da ação humana. E essa ação é entendida durante toda a obra como a própria poesia, que enquanto ação e produção exclusiva do homem se encontra em posição privilegiada para revelar a ele o lugar ao qual pertence. A poesia, a arte, é o fazer mais próprio do homem, já que é radicalização do modo de estar no mundo artificialmente, de produzir artifícios que não existem naturalmente, mas somente a partir da intervenção no mundo natural. Nesse sentido, também toda atividade humana é arte, é poesia, e toda atividade humana reflete um modo de estar no mundo que é de produção não natural, mas artificial.

Esse lugar que ocupa o fazer humano, a sua não identidade com o modo de ser da natureza, tem origem na chegada dos deuses ao Olimpo, onde nasce a nova lei, uma separação em relação à natureza que já é em si um esquecimento dela. A frase que abre o livro e o mundo mítico de Pavese é uma interdição, como se antes desta proibição inicial a fala do mundo fosse impossível, e talvez nem mesmo fala houvesse. Diz a Nuvem, Néfele: "Existe uma lei, Íxion, à qual é preciso obedecer [...] Existe uma lei, Íxion, que antes não existia". ${ }^{2}$

Não que não existisse lei alguma. O que é inaugurado não é uma lei que governa o cosmos e os que nele habitam, mas a lei que é enquadramento, não liberdade: o que é novo é a sua exigência de ser obedecida. "Um limite foi imposto a vocês, homens. A 
água, o vento, a rocha e a nuvem não são mais coisas suas, vocês não podem mais possuí-las, gerando e vivendo. Agora, outras mãos comandam o mundo. Existe uma lei, Íxion". ${ }^{3}$ As coisas do mundo não pertencem ao homem, ele não pode com elas se fundir e apreendê-las na sua totalidade. O primeiro diálogo é a repetição insistente da violência instaurada pela nova lei, a violência que dá forma ao destino humano e define a sua relação com o mundo, pautada pelo limite que impossibilita a sua total identidade com ele.

A possibilidade de reconciliação com a natureza é uma falsa promessa, e o homem está condenado a viver com ela numa relação de dominação. Toda vez que ele toca a natureza, esta o sente como uma intervenção violenta:

já não pode misturar-se conosco, as ninfas das nascentes e dos montes, e às filhas do vento, às deusas da terra. Mudou o destino. [...] pretendendo fazer isso, você faria algo de terrível. Como quem, para acariciar um companheiro, o estrangulasse ou fosse por ele estrangulado. ${ }^{4}$

Um dia o homem foi senhor da terra, não no sentido de que a subjugava, mas de que vivia nela como apenas uma entre as muitas criaturas que ela gerava, vivendo como elas, se fundindo com elas, gerando e vivendo. $O$ advento da lei olímpica instaurou uma eterna luta pela sobrevivência do homem, que necessita estrangular a natureza para não ser estrangulado. $O$ destino mudou porque a natureza daqueles que governam o mundo, os deuses olímpicos, é necessariamente diferente daquela das coisas que simplesmente existem:

Íxion, você acredita que sejam potências como nós, como a Noite, a Terra ou o velho Pan. Você é jovem, Íxion, mas nasceu sob o velho destino. Para você não existem monstros, mas somente companheiros. Para vocês a morte é uma coisa que acontece, como o dia e a noite. Você é um dos nossos, Íxion. Você está inteiro em cada gesto. Mas para eles, para os imortais, os seus gestos têm um sentido que se prolonga. Eles sentem tudo de longe com os olhos, o nariz, os lábios. ${ }^{5}$

Não é possível viver como os animais e as potências naturais, vindo a ser e morrer como a noite e o dia, vivendo no percurso da existência o puro acontecimento presente e ganhando satisfação na integralidade do gesto puro desprovido de sentido. As coisas do mundo percebem essa diferença fundamental do homem, para quem a única relação possível é o subjugar. Diz a ninfa Britomártis: "Nossa vida é folha e tronco, bolha d'água, espuma de onda. Brincamos de aflorar as coisas, não fugimos. Mudamos. Este é o nosso desejo e o destino. Nosso único terror é que um homem nos possua, nos detenha. Aí sim é que seria o fim". ${ }^{\circ}$

Para os animais todo instante é pleno, só há o presente que não aponta para um sentido fora de si. Para os homens não é mais possível sorrir, como diz Britomártis: "Sorrir é viver feito uma onda ou uma folha, aceitando a sorte. É morrer sob uma forma e renascer em outra. É aceitar, aceitar a si própria e ao destino". ${ }^{7}$ Aceitar o presente sem tentar 
compreendê-lo ou alterá-lo. Os imortais instauraram para o homem o ato de nomear as coisas, de fazer com que nada mais possa ser fruído como puro instante presente, mas tudo ganha razão de ser apenas no sentido que prolonga o gesto.

"O mundo é mais antigo do que eles. Já enchia o espaço e sangrava, gozava, era o único deus - quando o tempo ainda não havia nascido. Reinavam então as próprias coisas. Aconteciam coisas - agora, através dos deuses, tudo é feito, palavra, ilusão, ameaça" ${ }^{8}$, fala Tirésias a Édipo. O único deus, o mundo que sangra e goza, as coisas reinantes em seu simples acontecimento, são muito anteriores às palavras proferidas pelos deuses, são anteriores ao tempo, vivem no seu presente próprio.

Os deuses são esses que nomeiam os acontecimentos, arrancando-os de sua simples existência, seu verdadeiro modo de estar no mundo. Essa é a nova lei, instaurada pelos novos habitantes do mundo, os deuses e os homens. Continua Tirésias, adivinho cego: "Você é jovem, Édipo, e como os deuses que são jovens, você mesmo torna claras as coisas e dá nome a elas. Ainda não sabe que embaixo da terra existem rochas e que o céu mais azul é o mais vazio". ${ }^{9} \mathrm{O}$ nomear, a linguagem, aparece então em Pavese como uma falha em se ater às coisas nelas mesmas, uma falta de fidelidade com o ser próprio das coisas. A linguagem simboliza a queda do homem do paraíso. Ela aponta para a impotência da fala humana de dar conta da multiplicidade da existência, impotência em, de fato, "tornar claras as coisas", e a partir disso orientar a ação.

O acontecimento não pode ser capturado em sua essência pela linguagem, ele sempre deixa a totalidade escapar a ela. A fala é uma impossibilidade de controlar o fluxo do mundo:

Observe um rapaz que toma banho no Asopo. Manhã de verão. O rapaz sai da água, torna a entrar, mergulha e volta a mergulhar. Passa mal e se afoga. O que têm os deuses a ver com isso? Deverá atribuir o seu fim aos deuses ou então ao prazer desfrutado? Nem uma coisa nem outra. Aconteceu algo - que não é bom nem mau, alguma coisa que não tem nome -, depois os deuses lhe darão um nome. ${ }^{10}$

O que a palavra tem o poder de fazer é interferir nas coisas, mudando o seu estatuto: "os deuses podem alterá-las, aproximá-las ou afastá-las. Podem igualmente não tocar, não mudar as coisas". ${ }^{11} \mathrm{E}$ é só a partir desse nomear que caracteriza os deuses e homens é que as coisas do mundo tomam lugar na nossa experiência. O processo de nomear é, então, o de tornar assimilável para a experiência humana as múltiplas impressões da sensibilidade, para que assim ele possa se orientar de acordo com o modo como ele altera, aproxima, ou afasta as coisas de si, organizando a sensibilidade de um modo inteligível.

O problema é que esse nomear pertence propriamente aos deuses, são eles que têm a possibilidade de criar no mundo, de ordená-lo de acordo com a sua vontade, e não o homem. A cegueira de Tirésias Ihe mostrou como esse nomear humano é ilusão que não 
é capaz de nos tornar senhores no mundo. Como é dito na introdução ao diálogo de Pavese, o jovem Édipo que tenta tornar claras as coisas encontrou essa verdade na sua cegueira, quando "abriram-se os olhos que ele mesmo cegou de horror". ${ }^{12} \mathrm{O}$ horror é que o acontecimento abateu-se sobre ele sem qualquer possibilidade de controle racional, o horror que o fez cegar os olhos é a ineficácia de todo seu conhecimento no controle de seu destino. Todo seu esforço por deixar as coisas claras só revela a desgraça de saber que esse procedimento é impossível e ilusório. Édipo não cai em desgraça por desrespeitar códigos éticos fundamentados pelo seu conhecimento, mas sim por não ter a possibilidade, enquanto homem, de conhecer todas as forças que atuam na sua vida, de conhecer as suas próprias ações que se inserem neste conjunto de forças.

A luz que torna tudo claro, que abre o caminho para o conhecimento humano, falha em sua promessa emancipatória. E o homem, enquanto herdeiro dos deuses, se revela como "filho de uma luz ofuscante, cruel, e terá que viver num mundo de sombra exangue e angustiante, de carne corrompida, de suspiros e de febres - tudo the vem do Radioso". ${ }^{13}$ Apolo, o Radioso, deus das formas claras, é também o deus da luz que ofusca, encobre, não permite o conhecimento claro e distinto. "A mesma luz que o gerou assolará o mundo, implacável, e em qualquer lugar lhe mostrará a tristeza, a praga, a vileza das coisas". ${ }^{14} \mathrm{O}$ homem herda do deus a luz que cria e revela o mundo, mas essa luz também revela no mundo todo o horror que se volta contra os homens. Essas são palavras do centauro Quíron, o mesmo que será reinterpretado na produção de outro artista italiano do século XX, Pier Paolo Pasolini. No filme Medea, o centauro diz:

Tudo é santo. Tudo é santo. Tudo é santo. Não há nada de natural na natureza, meu pequeno. Guarde isso na memória. Quando a natureza lhe parecer natural, tudo terá acabado e começará qualquer coisa outra. Adeus céu, adeus mar. Que belo o céu! Próximo. Feliz. Diga, te parece mesmo que algum pedacinho dele seja natural e que não pertença a um deus? Assim como o mar, neste dia em que você completa 13 anos, e pesca com os pés na água morna. Olhe atrás de você. O que vê? Talvez alguma coisa de natural? Não! é uma aparição o que você vê atrás de você. Como as nuvens que se espelham na água parada, pesada, das três da tarde. Olhe lá longe aquela tira negra sobre o mar, brilhante como o azeite. Aquelas sombras de árvores e aqueles canaviais. Em cada ponto que seus olhos veem, está escondido um deus. E se por acaso não está, aí deixou sinais de sua presença sagrada. Ou silêncio, ou cheiro de erva, ou frescor de água doce. Sim, tudo é santo, mas a santidade traz consigo uma maldição. Os deuses que amam também odeiam. ${ }^{15}$

Não há nada de natural na natureza, tudo com o que se confronta o homem é pertencente ao divino. O natural é palavra, aparência, produção do deus que poetiza o mundo. Tudo que o homem vê à sua volta tem seu vir a ser na ordem do sagrado. As coisas não mais existem por si, mas na medida em que são criadas pelos deuses e pertencentes à ordem cósmica da qual estes fazem parte. Mas ao mesmo tempo, diz o centauro que "sim, tudo é santo, mas a santidade traz consigo uma maldição. Os deuses que amam também odeiam". A criação poética do deus pode, portanto, ser tanto bela quanto terrível. 
Diz Tânatos, em Pavese, sobre os deuses olímpicos: "Cada capricho deles é uma lei fatal. Para dizer uma flor, destroem um homem". ${ }^{16}$ Apolo matou Jacinto porque pensou criar uma flor. A criação divina é sempre também um ato destrutivo, as vontades dos deuses dizem respeito a uma ordem que não é acessível aos mortais, não fazem parte de sua razão, seus desejos, sua compreensão de mundo, e por isso "quando um deus se aproxima de um mortal, sempre se segue uma coisa cruel". ${ }^{17} \mathrm{~A}$ criação como destruição está muito presente no pensamento trágico grego, e um dos mais importantes filósofos trágicos, Heráclito, o expressou na figura de um jogo. Segundo ele, "o tempo é uma criança brincando, jogando: reinado da criança". ${ }^{18}$

A morte e a destruição não devem ser pensadas como resultado de um princípio moral. O que vem a ser, a criação em Heráclito, deve ser visto como um jogo do fogo consigo mesmo, onde não há finalidade a não ser a saciedade deste fogo e nenhuma motivação além da carência deste de consumir. O mundo se consome, portanto, segundo a necessidade de carência e saciedade do fogo, se transformando neste jogo eterno. $O$ tempo é o resultado do jogo de uma criança ou da criação de um artista, e a sua disposição inocente para criar e destruir revela-se como a maior das justiças, que o homem tem tanta dificuldade em aceitar, pois é a justiça que o submete à escravidão do acaso e da incerteza, que lhe causa a incômoda sensação de estar sempre à deriva, sem ter onde achar terra firme para se prender.

É essa visão trágica que orientou Pavese na sua retomada dos deuses gregos. A criação do artista ou da criança obedecem a princípios divinos que podem nos parecer tão inúteis como a criação de uma flor. Esse ato criativo nos aparece como totalmente desprovido de sentido, "um capricho", diz Eros, "o Radioso quis brincar. Desceu entre os homens e viu Jacinto [...] Depois, quando o senhor quis ir embora, Jacinto o olhava perdido. Então o disco caiu-lhe entre os olhos". ${ }^{19}$

A arbitrariedade da criação divina é insuportável para a razão humana, que buscará lhe dar sentido. Um deus antigo, Tânatos, sabe da impossível correspondência dos desejos divinos e mortais: "Por onde passou um imortal, sempre brotam flores assim", flores nascidas do sangue humano. Todo encontro com o divino resulta em criação, e essa criação exige um sacrifício. Mas mesmo o deus antigo é tomado de compaixão pelo destino dos mortais: "nas outras vezes, pelo menos havia uma fuga, um pretexto, uma ofensa. Resistiam ao deus ou cometiam ações ímpias [...] Mas Jacinto não passou de um rapaz. Viveu seus dias venerando o seu senhor. Brincou com ele como brinca uma criança”. ${ }^{20}$

Como poderia ter Jacinto se afastado de seu destino, que erro cometeu para nele se enredar, são questões que não podemos responder de acordo com nosso universo moral. Seu desejo e sua morte são intoleráveis para uma mortal como Safo: 
Pode-se aceitar que uma força rapte você, que você se torne desejo, desejo trêmulo debatendo-se ao redor de um corpo de companheiro ou de companheira, como a espuma entre os abrolhos? E esse corpo rechaça e quebranta você, e você torna a recair e gostaria de abraçar o rochedo, aceitá-lo. Outras vezes você própria é o rochedo, e a espuma - o tumulto - se debate a seus pés. Ninguém mais consegue ter paz. É possível aceitar tudo isso ${ }^{21}$

Tudo é desígnio do deus, o tumultuoso jogo do rochedo com a espuma não pertence aos homens, mas o desejo mesmo pertence ao reinado de Afrodite, essa para quem "tudo que se esmaga e debate no mar é sua substância e respiração". ${ }^{22} \mathrm{O}$ que poderia ser visto como o mais próprio do homem, seu desejo, não está sob o seu controle, e por isso nem mesmo ele é facilmente aceitável, como diz Safo. O sentimento intolerável é também o de Édipo, para quem os crimes que cometeu não são atrozes em si, mas sim porque ele não os realizou de acordo com um desejo que lhe fosse próprio:

Ousei acreditar apenas em meus pensamentos, nos instantes de trégua, nos ressurgimentos imprevistos. Fiquei sempre de atalaia. E não escapei. Exatamente naqueles instantes o destino se cumpria. [...] Gostaria que [meus crimes] fossem mais atrozes ainda. Gostaria de ser o homem mais imundo e mais vil desde que aquilo que fiz tivesse sido desejado - e não suportado assim, não realizado assim, quando queria fazer outra coisa. O que resta de Édipo, o que somos todos nós, se até a vontade mais secreta de seu sangue já existia antes que você nascesse e tudo já estava dito? ${ }^{23}$

O que é o homem se até sua mais secreta vontade pertence aos deuses, se "tudo já estava dito", ou seja, poetizado pelos deuses? Os deuses são aqueles que nomeiam e criam, destruindo os homens de acordo com o seu desejo. Édipo sabia disso, ouviu o oráculo, e não conseguiu evitar a desgraça: "minha febre é meu destino - o medo, o horror perene de cumprir exatamente a coisa sabida. Eu sabia - sempre soube - agir como o esquilo que acredita estar subindo e só faz girar a gaiola. E me pergunto: quem foi Édipo?"24

Os deuses, para a sobrevivência dos homens e a abertura da possibilidade de construção de seu próprio destino, deverão desaparecer. $O$ tema da morte dos deuses tem uma importância decisiva ao longo de todo o romance. O próprio Tânatos, mais velho que os olímpicos, é um dos primeiros que vem ressaltar o fim deles: "Que para nascer seja preciso morrer, isso até os homens sabem. Não o sabem os Olímpicos. Esqueceram-se disso. Eles perduram num mundo que passa". ${ }^{25}$ Também Quíron, quando Hermes lhe pergunta se o reinado do Olimpo não é melhor que a lei antiga, responde: "Enquanto o Olimpo for céu, certamente. Mas essas coisas passarão". ${ }^{26}$

Mas é Prometeu que, como na tragédia, irá anunciar com maior ênfase o seu fim. A morte dos deuses deve se consumar, diz Prometeu, para permitir a vida humana. "Mas todas as coisas não nos vêm deles?"27, Ihe pergunta Hércules. A resposta nos remete novamente ao mundo sem linguagem, das coisas existentes no mundo quando o Olimpo não era habitado: 
Prometeu - Hércules, existe uma sabedoria mais antiga. O mundo é velho, mais do que este rochedo. $\mathrm{E}$ também eles o sabem. Cada coisa tem um destino. Mas os deuses são jovens, quase tão jovens quanto você [...] Mas houve tempo em que eu era um titã e vivi num mundo sem deuses. Também isso aconteceu... Não consegue imaginar um mundo assim?

Hércules - Não é o mundo dos monstros e do caos?

Prometeu - Dos titãs e dos homens, Hércules. Das feras e dos bosques. Do mar e do céu. É o mundo de luta e sangue, que fez de você o que é. Até o último deus, o mais iníquo, era então um titã. Não há coisa que permaneça, no mundo presente ou futuro, que não fosse titânica.

Hércules - Era um mundo de pedras. ${ }^{28}$

O mundo era então pesado, de pedras. Antes do ordenamento realizado pelos deuses, através do ato de dar nomes às coisas, não havia fala, linguagem nenhuma que pudesse conduzir a erro, e tudo era de acordo com o seu destino. O titânico assume o lugar do eterno, da natureza bruta inalterável. Os deuses vieram e impuseram ordem, fala, beleza (ordem em grego, cosmos, guarda também o sentido de beleza, como uma bela ordenação). Com isso introduziram um tempo que não é mais o da eternidade, mas que tem duração, tem morte: "A morte entrou nesse mundo junto com os deuses. Vocês mortais temem a morte porque sabem que, como tais, os deuses são imortais. Mas cada um tem a morte que merece. Também eles perecerão". ${ }^{29}$

Como viverá o homem após a morte dos deuses, se o passado está perdido para sempre, se aquela pesada existência pura das coisas é inacessível? O futuro da humanidade, responde Prometeu, é não mais temer a relação com o divino, e aí o divino morrerá: "Quando os mortais não tiverem mais medo, os deuses desaparecerão". "Voltarão os titãs?", pergunta Hércules.

Prometeu - Não retornam os seixos e as selvas. Existem. O que foi será [...] Somos um nome, nada mais. Entenda-me, Hércules. E o mundo tem estações, como os campos e a terra. Retorna o inverno, retorna o verão. Quem pode dizer que a selva há de perecer? Ou que perdure? Vocês serão os titãs, dentro em breve.

Hércules - Nós mortais?

Prometeu - Vocês mortais - ou imortais, não importa. ${ }^{30}$

Mortos os deuses e os titãs, sem temer mais as mãos que comandam o seu destino, o submetem a forças cujo sentido não é reconhecido, os homens serão os titãs, estarão livres para construir seu próprio caminho no mundo. O homem, já separado do seio da natureza, realiza a sua libertação completa através da perda do medo dela, e isso pretende ser realizado a partir da progressiva dominação de todos os seus aspectos. As 
forças provenientes do mito que irrompem em sua existência e destroem qualquer tentativa de construção autônoma do seu destino devem ser suprimidas em nome da sobrevivência desse homem.

A resposta para a sobrevivência do homem frente à arbitrariedade dos deuses é dada então pela técnica, que promete tornar o homem senhor definitivo da natureza, subjugando-a para cada vez mais se emancipar frente ao poder dos mitos. Só não se pode temer aquilo que já foi devidamente conhecido, classificado e não representa mais uma ameaça. Quando a técnica imperar os deuses finalmente terão sido mortos e a humanidade viverá seu momento de apogeu.

Aqui nos aproximamos daquele motivo pelo qual Pavese se decidiu por escrever um livro recontando os mitos gregos, a sua descrença de que fossem "esquisitices inúteis" e seu empenho por encontrar neles "o segredo de algo que todos recordam". Pois a ameaça da natureza nos parece realmente só persistir hoje enquanto uma lembrança muito distante. Não há mais no mundo contemporâneo muitos lugares onde esta ameaça é realmente sentida como uma força natural e à primeira vista os deuses estão realmente mortos.

Mas, apesar da morte dos deuses, também parecia bem claro a Pavese, começando a redigir seus diálogos durante a Segunda Guerra Mundial, que o projeto que deveria emancipar o homem pela técnica fracassou. Duas guerras das mais brutais conhecidas pela Europa, o extermínio calculado de milhões de seres humanos em campos de concentração, os regimes totalitários formados no seio da civilização ocidental, e, acima de tudo, o capitalismo que aparece como a realização extrema do mundo administrado onde a liberdade do homem sofre a maior negação com a qual já se deparou, tudo isto nos mostra que o projeto de formar um caminho baseado na pura vontade racional humana não se concretizou.

Ao contrário, esse passado mítico que Pavese se recusou a ver como morto volta a nos confrontar a toda vez:

Mas essa técnica emancipada se confronta com a sociedade moderna sob a forma de uma segunda natureza, não menos elementar que a da sociedade primitiva, como provam as guerras e as crises econômicas. Diante dessa segunda natureza, que o homem inventou mas há muito não controla, somos obrigados a aprender, como outrora diante da primeira. ${ }^{31}$

Esta frase de Benjamin ganha eco na fala de Prometeu a Hércules, que logo depois de anunciar a morte dos deuses e o advento do homem como força titânica e senhor do mundo afirma que "não se matam os monstros. Nem sequer os deuses podem fazê-lo. [...] Não se pode dizer tudo. Mas lembre-se para sempre de que os monstros não morrem. O que morre é o medo que eles incutem em você. Assim é com os deuses". ${ }^{32} \mathrm{O}$ medo da natureza, dos deuses e monstros, potências míticas de destruição do homem, 
desapareceu, mas eles não estão mortos. "Alguma vez se perguntou para onde vão os velhos deuses que o mundo ignora?", pergunta Calipso a Ulisses; "Por que mergulham no tempo, como as pedras na terra, eles que também são eternos?" ${ }^{33}$ As forças que influíam no destino humano e o controlavam são eternas, foram apenas reprimidas através do esquecimento, e aquilo que é reprimido retorna em fúria vingativa contra a civilização.

A técnica não foi capaz de proporcionar ao homem o seu domínio sobre o mundo. Como diz Benjamin, "a sociedade não estava suficientemente madura para fazer da técnica o seu órgão, e a técnica não estava suficientemente avançada para controlar as forças elementares da sociedade". Entregar a sorte do homem à técnica reflete a ilusão em supor como mortas as forças elementares da sociedade, os monstros e deuses que ela esqueceu de temer. "Essa guerra", a destruição que impera no mundo contemporâneo, "é uma revolta da técnica, que cobra em 'material humano' o que lhe foi negado pela sociedade" ${ }^{34}$ Os sacrifícios humanos que eram dedicados à criação dos deuses são agora efetuados em nome de uma mesma força mítica que continua a subjugá-lo.

Pavese escreveu seus diálogos numa tentativa de repensar o estatuto da produção humana e como ela pode se relacionar com o mundo externo dominado completamente pela técnica, agora reconfigurado no mundo mítico com o qual se confrontou o homem primordial, e que coloca novamente aos modernos a questão de como nele sobreviver. A resposta de Pavese é a poesia, o trabalho do poeta que procura ser de novo a voz criadora dos deuses, completamente silenciada pelo mundo contemporâneo. É dar vida aos deuses que foram esquecidos, revelar novamente para os homens a vida que estes acreditaram ter suprimido. Isso é expresso no diálogo que mais diretamente trata da atividade da poesia em todo o livro, que é justamente aquele entre Hesíodo e Mnemósine:

Mnemósine - Não entende que o homem, todo homem, nasce naquele palude
sanguinolento? E que o sagrado e o divino acompanham também vocês, dentro do leito,
no campo, diante da chama? Cada gesto que fazem repete um modelo divino. Dia e
noite, vocês não dispõem de um instante, nem mesmo do mais fútil, que não brote do
silêncio das origens.

Hesíodo - Você fala, Mélite, e não posso resistir. Bastaria que a venerasse.

Mnemósine - Existe outro modo, meu caro.

Hesíodo - Qual?

Mnemósine - Tente dizer aos mortais estas coisas que sabe. ${ }^{35}$ 
O poeta reconhece que a potência criativa dos deuses está no homem, é o homem que pode trazer à presença o divino. A função do poeta é trazer à luz, resguardar contra o esquecimento aquilo que se achava perdido na natureza, revelar a existência dos deuses para os outros homens. Ou como diz Dionísio a Deméter:

Os mortais são divertidos. Sabemos as coisas, e eles as fazem. Sem eles me pergunto o que seriam os dias. O que seríamos nós olímpicos. Chamam-nos com suas vozinhas e nos dão nomes. Têm um modo de nomear a si próprios e às coisas e a nós que enriquece a vida [...] Onde quer que espalhem trabalhos e palavras, nasce um ritmo, um sentido, um repouso. ${ }^{36}$

Ao que responde Deméter:

É verdade. Tudo o que tocam se torna tempo. Torna-se ação. Espera e esperança. [...] Sabem dar nomes que nos revelam a nós próprios, laco, e nos arrancam da pesada eternidade do destino para nos colorir nos dias e nas aldeias por onde andamos. [...] Quem diria que em sua miséria possuem tanta riqueza? [...] Tudo devo a eles. ${ }^{37}$

A atividade do homem é aquela então de colorir os deuses, dar-lhes vida, arrancando-os da "pesada eternidade do destino". Apropriando-se daquilo que encontram de divino em si, ou seja, o nomear, criar, poetizar, o homem tem como potência o fazer nascer "um ritmo, um sentido, um repouso". Aquilo que encontra de aparentemente inalterável, o que parece que está aí naturalmente, a pesada existência das coisas sem fala, é modificada pelo toque humano que transforma tudo em ação, tempo, espera e esperança. Para o artista nada se encontra imóvel e natural no mundo, tudo é construção dos deuses, e tudo pode ser reconstruído. Sua miséria maior, a não identidade com o natural, se revela como também uma riqueza.

No mundo contemporâneo, em que todo produzir se reduz ao trabalho e à técnica que visam à reprodução do mesmo, o poeta deve trazer de volta a atividade da poesia como criação que abre um outro modo de ver e se relacionar com as coisas. Mas não a criação em si, a criação do gênio, que supõe que se pode criar uma obra a partir do espírito, mas criação de vida, de sentido, criação de si. É a criação que tem como objetivo a formação ética do homem fundada na poesia. A tentativa de Pavese é, através de sua criação como artista, transformar a vida cada vez mais em poesia, e tornar sua poesia cada vez mais viva. A criação poética que Pavese retoma dos gregos não tem como interesse ser objeto de contemplação estética:

O sentido da ação poética e moral de Pavese encontra-se na laboriosa passagem entre dois modos de estar no mundo: partindo de um dado de passividade e anonimato existencial, chegar a transformar tudo que vivamos em autoconstrução, consciência, necessidade. Uma operação poética e moral, digamos. Enquanto poética, significará sair de uma concepção de criação como abandono à confissão lírica ou ao prazer do gosto compositivo ou do reconhecimento naturalista do mundo externo, para chegar por meio de uma árdua via de exclusões e reduções, até imagens que sejam nódulos de experiência insubstituíveis, comunicações absolutas em todos os níveis. Como opção criativa, significará escavar e escavar o caráter cotidiano de imagens cinzentas, de 
presenças sem rosto, de falas rústicas e descuidadas, como se apresentam na impoética cidade industrial, no impoético Piemonte agrícola e interiorano, até que se alcance um espaço e uma cor interna à página, um sistema de relações que adquira espessura, uma linguagem calibrada. Em resumo: um estilo. ${ }^{38}$

A construção poética de Pavese é a construção de um estilo, pensado não enquanto "sobreposição de uma cifra e de um gosto, mas escolha de um sistema de coordenadas essenciais para exprimir nossa relação com o mundo". ${ }^{39}$ Resume o tema da filosofia trágica de Pavese o fato de que ele pensou o modo de viver e criar no mundo contemporâneo com o nome de "ser tragicamente". Com isso pensava que o artista deve manter em sua relação com o mundo aquele olhar que Ihe foi passado pela tragédia, a impossibilidade de controlar o seu destino, de superar o lugar limitado que the foi concedido no mundo. Reconhecer, portanto, o quanto o percurso de sua vida é essencialmente indomável e inapreensível em sua totalidade, mas, assim como o herói trágico, lutar para fazer valer a sua ação, para construir o seu lugar no mundo.

O objetivo era portanto transformar toda sua vida e obra em tragédia, transformar essa vivência individual em possibilidade de compreensão e autoconstrução, isto é, mobilizar seu caráter essencialmente criador para a construção de sentido no mundo, mas não com a ilusão de fazer valer no fluxo do mundo a sua livre vontade racional (como presente em algumas teorias do gênio). Ser tragicamente em Pavese é se lembrar da existência dos deuses, e a partir disso tentar construir em meio a eles uma história. É, como diz Calvino:

conduzir o drama individual [...] a uma força concentrada que marque por si só todo tipo de ação, de obra, todo fazer humano, significa transformar o fogo de uma tensão existencial num agir histórico, transformar o sofrimento ou a felicidade privada, essas imagens de nossa morte [...], em elementos de comunicação e de metamorfose, isto é, em forças de vida. ${ }^{40}$

Ser tragicamente é tirar a arte do domínio da estética e incorporá-la ao percurso de uma vida, trazê-la de volta para a história, transformá-la em necessidade. É recusar a pura contemplação das coisas naturais e observá-las com aquele olhar do centauro Quíron que vê em todas o princípio da criação divina. Nesse mundo o artista deve criar também para si um sentido, um estilo, uma moral, uma atitude frente à vida que fosse fundamentada na arte, um reencontro com a voz do deus criador. Criação, portanto, de uma linguagem, expressão de uma nova relação com o mundo: um estilo que contenha em si mesmo uma nova possibilidade de existência do homem. Enxergar o processo através do qual as coisas vieram a ser, para a partir daí vislumbrar a abertura de uma nova relação com elas. A volta dos deuses não deve então ser vista apenas como a submissão dos homens a uma força superior que os transcende, mas deve fazer lembrar a potência do homem de criar para si um novo modo de existência.

No último diálogo do livro de Pavese assistimos ao encontro de dois homens que não são personagens do mito, não têm nome, são seres anônimos. Estes homens são os 
nossos contemporâneos, "nós que vivemos longe, à beira-mar ou nos campos", definidos por uma falta: "a outra coisa, nós a perdemos [...] Aqueles encontros com eles". ${ }^{41}$ Este diálogo se intitula Os deuses, em referência àqueles cuja presença não mais sentimos. É na atividade da poesia que os encontros podem novamente nos propiciar um modo de estar no mundo que seja autenticamente construtivo, que possa nos oferecer o vislumbre de outros mundos possíveis e a superação do mundo administrado pela técnica.

* Daniel Alves Gilly é mestrando em filosofia pela UFF.

${ }^{1}$ PAVESE, C. Diálogos com Leucó. Tradução de Nilson Moulin. São Paulo: Cosac Naify, 2011, p. 19.

2 Ibidem, p. 21.

${ }^{3}$ Ibidem, p. 22.

${ }^{4}$ Ibidem, p. 23.

${ }^{5}$ Ibidem, pp. 24-25.

${ }^{6}$ Ibidem, p. 65.

7 Ibidem, p. 66.

8 Ibidem, p. 36.

${ }^{9}$ Ibidem, p. 37.

${ }^{10}$ Ibidem, p. 36.

${ }^{11}$ Ibidem.

12 Ibidem, p. 35.

${ }^{13}$ Ibidem, p. 42.

${ }^{14}$ Ibidem, p. 42.

${ }^{15}$ PASOLINI, P. P. Medea. Itália, 1969, 118 min.

${ }^{16}$ PAVESE, C. Op. cit., p. 52.

17 Ibidem, p. 48.

18 HERÁCLITO. Heráclito: Fragmentos contextualizados. Tradução, estudo e comentários de Alexandre Costa. São Paulo: Odysseus Editora, 2012, p. 75.

${ }^{19}$ PAVESE, Op. cit., p. 49.

${ }^{20}$ Ibidem, p. 48.

${ }^{21}$ Ibidem, p. 68.

22 Ibidem, p. 70.

${ }^{23}$ Ibidem, p. 91.

${ }^{24}$ Ibidem, p. 92.

${ }^{25}$ Ibidem, p. 52.

${ }^{26}$ Ibidem, p. 46. 
${ }^{27}$ Ibidem, p. 99.

${ }^{28}$ Ibidem, pp. 99-100.

${ }^{29}$ Ibidem, p. 103.

30 Ibidem, pp. 103-104.

${ }^{31}$ BENJAMIN, W. "A obra de arte na era de sua reprodutibilidade técnica". In: Obras escolhidas I: Magia e Técnica, Arte e Política. Tradução de Sérgio Paulo Rouanet. São Paulo: Brasiliense, 2012, p. 188.

${ }^{32}$ PAVESE, C. Op. cit., pp. 101-103.

${ }^{33}$ Ibidem, 136.

${ }^{34}$ BENJAMIN, W. Op. cit., p. 211.

${ }^{35}$ PAVESE, C. Op. cit., pp. 214-215

${ }^{36}$ Ibidem, pp. 193-194.

${ }^{37}$ Ibidem, p. 194.

${ }^{38}$ CALVINO, I. "Pavese: ser e fazer". In: PAVESE, C. Op. cit., p. 223.

${ }^{39}$ Ibidem, p. 224.

${ }^{40}$ Ibidem, p. 227.

${ }^{41}$ PAVESE, Op. cit., p. 219. 